\title{
Sterculia striatiflora Mast (Malvaceae s.l.) - A new addition to the flora of Assam
}

\author{
Manash Baruah $^{1 *}$, Debolina Dey ${ }^{1}$, Saurav Kumar Boruah ${ }^{1}$, Monish Paul ${ }^{1}$, Birina Bhyuan ${ }^{2} \&$ Nilakshee \\ Devi $^{1}$
}

${ }^{1}$ Department of Botany, Gauhati University, Gopinath Bordoloi Nagar, Guwahati 781 014, Assam, India

${ }^{2}$ Department of Botany, Bodoland University, Kokrajhar 783 370, Assam, India

*Email: manashbaruah@gauhati.ac.in

\section{ARTICLE HISTORY}

Received: 14 April 2021

Accepted: 15 May 2021

Available online: 01 July 2021

ABSTRACT

KEYWORDS

Sterculia striatiflora Mast, a rarely known species of Malvaceae s.l., is reported here as a new distribution record and addition to the Flora of Assam, India. A detailed description, colour photographs and other relevant information has been provided for its identification.

New record; Sterculiaceae;

Lakhimpur; Dullung Reserve Forest

\section{Introduction}

The broad circumscription of Malvaceae s.l. is known to comprise of 4 traditional families viz. Bombacaceae, Sterculiaceae, Tiliaceae and Malvaceae. It also consists of 245 genera and 4300 species distributed throughout the world especially in the tropics $(1,2)$. The subfamily Sterculioideae Beilschm., designated earlier as Sterculiaceae (DC) Bartl., is a monophyletic group having four major clades of which genus Sterculia L. belongs to the clade Sterculia (3). The genus Sterculia L. has ca. 200 species reported worldwide (4). Thirty one species of the genus Sterculia has been reported in Hooker's Flora of British India (5). Eight species were recorded from the greater Assam (6). During a floristic survey to the Lakhimpur district of Assam in February 2021, the authors came across a plant specimen growing on the tropical moist deciduous forests of Dullung Reserve Forest. After thorough study and extensive consultation with the different existing literatures $(5,6)$ and herbarium specimens deposited at KEW, this plant was confirmed as Sterculia striatiflora Mast. Recent reports are there on the first occurrence of $S$. striatiflora in India from Arunachal Pradesh (7). A voucher specimen (MB001) has been submitted at the Gauhati University Botanical Herbarium (GUBH). A detailed description of the species, coloured photographs and other relevant information are provided here for its identification.

\section{Taxonomic treatment}

Sterculia striatiflora Mast. in Hook.f., Fl. Brit. India 1: 356. 1874. Clompanus striatiflora (Mast) Kuntze, Revis. Gen. Pl. 1: 78. 1891.

Perennial shrub, 45-50 cm high, bark greenishgrey. Leaves 12-25 × 4-7 cm, simple; lamina oblanceolate, entire, rarely undulate, tip acuminatecaudate, base cuneate; petioles $2-3 \mathrm{~cm}$ long, pulvinate below the lamina; stipules lateral, free, subulate-acuminate, 4-5.5 × 1-1.2 mm, green, pubescent, herbaceous. Panicles axillary, $3-8 \mathrm{~cm}$ long, male and female flowers on same inflorescence, lax, drooping; Pedicels capillary, 3-4 $\times 0.6-0.8 \mathrm{~mm}$ long; Bracts subulate, $2.8-3.3 \times 1-1.4$ $\mathrm{mm}$, green, persistent; rachis, petiole, bracts and peduncle densely pubescent. Flowers dioecious, drooping, $1.2-2 \times 0.6-0.8 \mathrm{~cm}$; calyx petaloid, pale yellow to dark pink, greenish towards the base, tube 3-4 mm, infundibuliform, lobes 5, lanceolate with margins reflexed outward, joining together at the tips, free in matured flowers, 8-10 mm long, both surfaces densely villous. Male flowers: staminal column 7-10 $\mathrm{mm}$ long, curved downwards, glabrous; anther lobes 5, somewhat triangular, yellow, dehiscing longitudinally; pollen yellow, granular. Female flowers: gynandrophore ca. $6 \mathrm{~mm}$ long, broadened towards the tip and 5-lobed, each bearing one sterile anther; ovary ca. $2 \mathrm{~mm}$ long,

C Baruah et al (2021). This is an open-access article distributed under the terms of the Creative Commons Attribution License, which permits unrestricted use, distribution and reproduction in any medium, provided the original author and source are credited (https://creativecommons.org/licenses/by/4.0/). 
densely villous, hemispherical with 5 lobes; style ca. $2.5 \mathrm{~mm}$ long, curved downward, greenishwhite; stigma 5-lobed. (Fig. 1 \& 2).

\section{Common Name}

Grooved Flower Sterculia

\section{Habitat}

The species was found growing on the tropical moist deciduous forests of Dullung Reserve Forest, Lakhimpur District, Assam.

\section{Phenology}

Flowering was observed in February. Fruits not seen.

\section{Distribution}

Myanmar (Burma), India [Arunachal Pradesh (East Siang District, Papum Pare District); Assam (Dullung Reserve Forest, Lakhimpur)]. Only a single population, comprising of 4 plants, were spotted by the authors growing in a sciophytic area in the present locality.

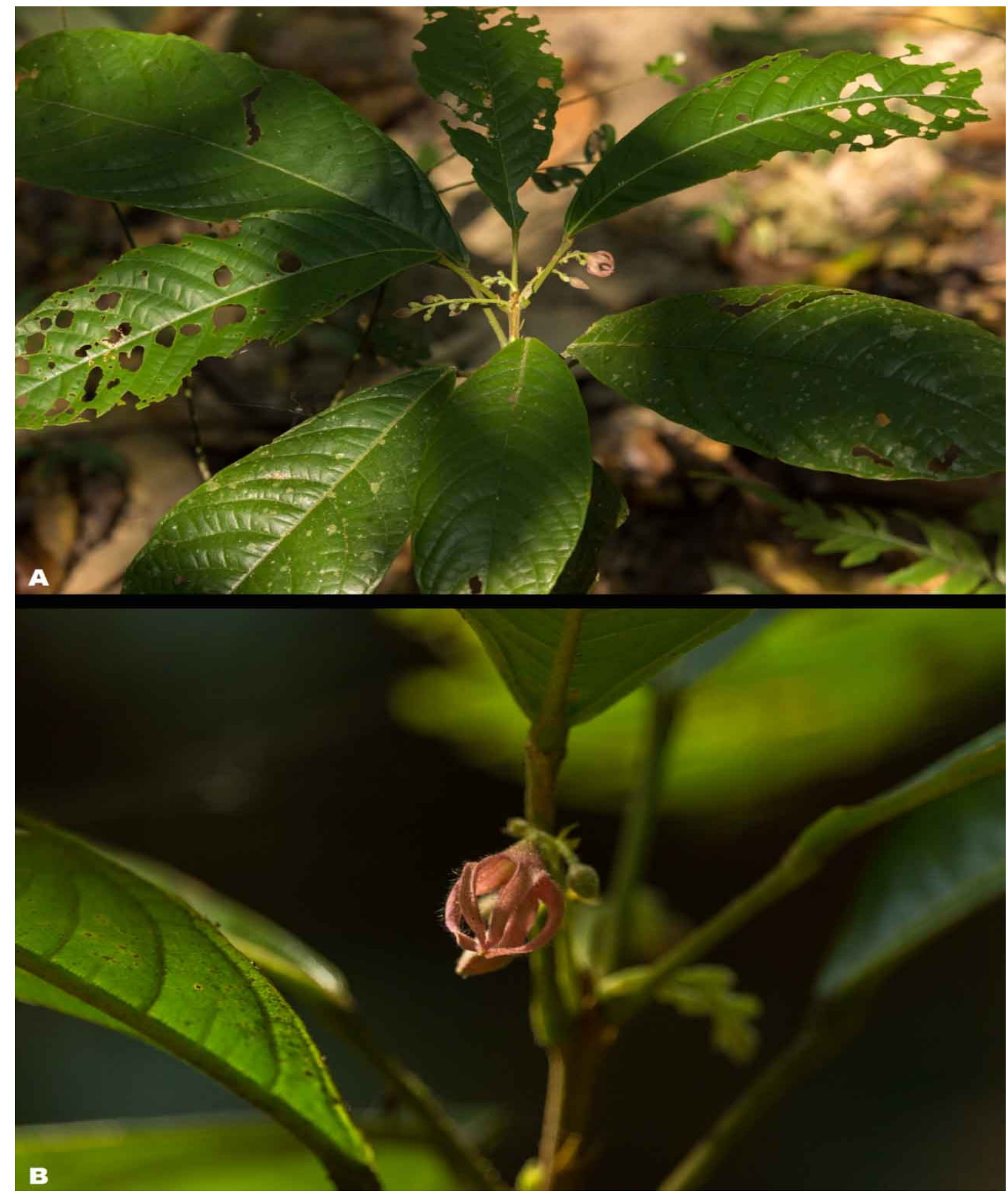

Fig. 1. Sterculia striatiflora Mast. A. Habit, B. Inflorescence. 

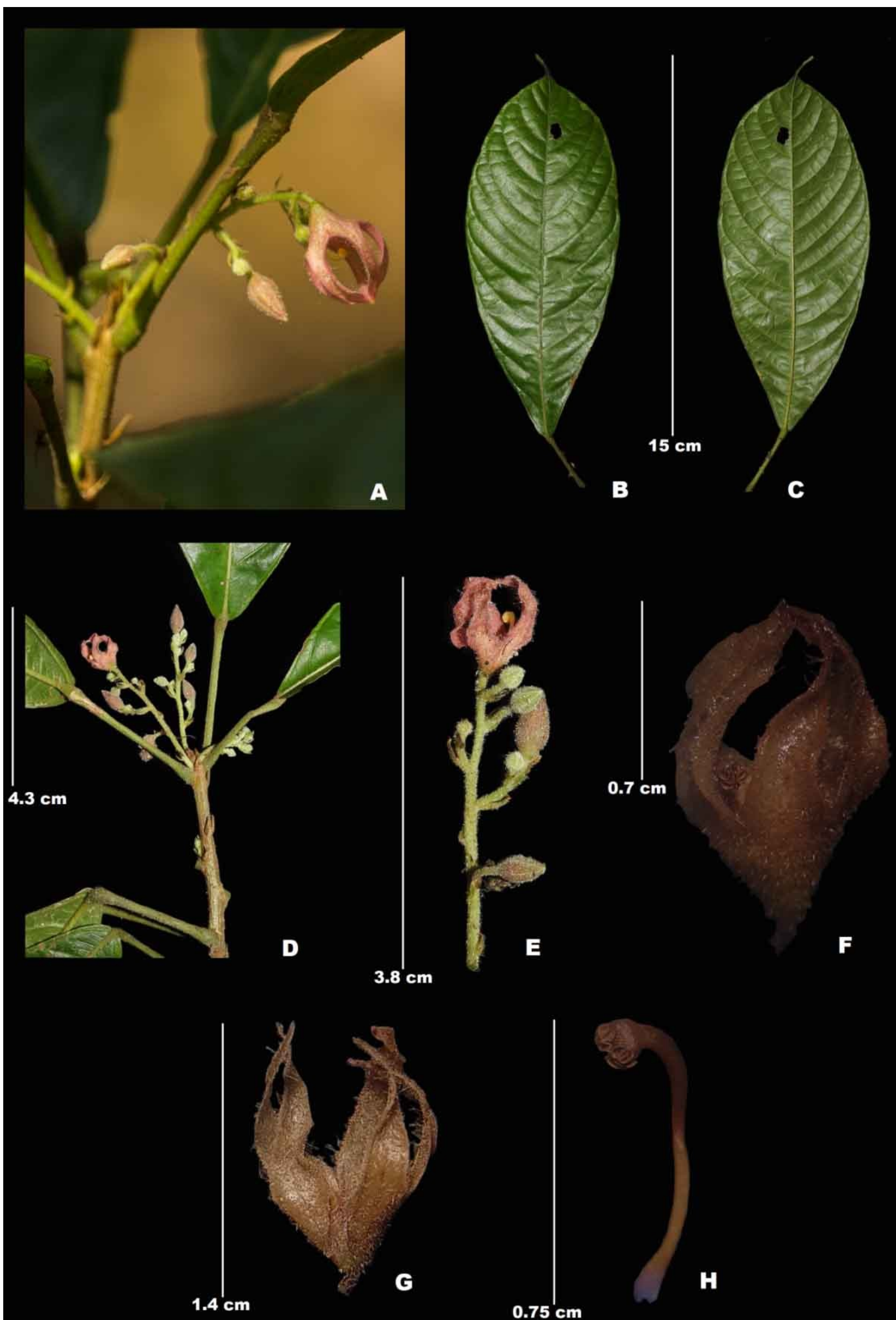

Fig. 2. Sterculia striatiflora Mast. A. Habit, B-C. Leaves, D. A part of the stem showing arrangement of leaves and inflorescence, E. Inflorescence, F. Flower, G. Corolla, H. Staminal column. 


\section{Specimen examined}

Myanmar (Burma), Kachin, 29 March 1837, s.coll., s.n. [Acc. No. K000671639 (image!) Holotype]. India, Assam, Lakhimpur district, Dullung Reserve Forest, $27.420003{ }^{\circ} \mathrm{N}, 94.193385^{\circ} \mathrm{E}, \pm 103.84 \mathrm{~m}, 05$ February 2021, M. Baruah MB001 (GUBH!).

\section{Acknowledgements}

The authors are grateful to the Board of Trustees, Royal Botanic Gardens, Kew; Dr. Souravyoti Borah, Curator, Gauhati University Botanical Herbarium (GUBH) and the officials of the Department of Forest and Environment, Govt. of Assam for providing aid and facilities during the field surveys.

\section{Authors' contributions}

MB, MP and ND have prepared the manuscript for correspondence. DD, SKB and BB had collected and identified the plant. All authors read and approved the final manuscript.

\section{Conflict of interests}

The authors have no competing interests.

\section{References}

1. Nyffeler R, Bayer C, Alverson WS, Yen A, Whitlock BA, Chase MW, Baum AD. Phylogenetic analysis of the Malvadendrina clade (Malvaceae s.l.) based on plastid DNA sequences. Organisms Diversity and Evolution. 2005;5(2):109-23. https://doi.org/10.1016/j.ode.2004.08.001
2. Balthazar MV, Schonenberger J, Alverson WS, Janka H, Bayer C, Baum DA. Structure and evolution of the androecium in the Malvatheca clade (Malvaceae s.l.) and implications for Malvacae and Malvales. Plant Systematics and Evolution. 2006; 260: 171-97. https://doi.org/10.1007/s00606-006-0442-9

3. Wilkie P, Clark A, Pennington RT, Cheek M, Bayer C, Wilcock CC. Phylogenetic relationships within the Subfamily Sterculioideae (Malvaceae/Sterculiaceae-Sterculieae) using the chloroplast gene ndhF. Systematic Botany. 2006; 31(1): 160-70. https://doi.org/10.1600/036364406775971714

4. Malick KC. Sterculiaceae. In: Sharma B.D. and Sanjappa M. (editors). Flora of India. Vol. 3. Botanical Survey of India, Calcutta; 1993. p. 407-76.

5. Masters MT. Sterculiaceae. In: Hooker JD, editor. The Flora of British India. Vol. 1. L. Reeve and Co Ltd: England; 1874. p. 353-79.

6. Kanjilal UN, Kanjilal PC, Das A, Purkaystha C. Flora of Assam. Vol. 1. Assam Govt. Press (Shillong); 1934. p. 149-60.

7. Borah D, Das AP. Rediscovery of Sterculia striatiflora Mast. (Malvaceae) and its new record for the flora of India. Pleione. 2018;12(1):105-09. http://dx.doi.org/10.26679/ Pleione.12.1.2018.105-109

\section{Additional information}

Peer review information: Plant Science Today thanks Sectional Editor and the other anonymous reviewers for their contribution to the peer review of this work.

Reprints and permissions information is available at

https://horizonepublishing.com/journals/index.php/PST/open_access_policy

Publisher's Note: Horizon e-Publishing Group remains neutral with regard to jurisdictional claims in published maps and institutional affiliations.

To cite this article: Baruah M, Dey D, Boruah S K, Paul M, Bhyuan B, Devi N. Sterculia striatiflora (Malvaceae s.I.) - A new addition to the flora of Assam. Plant Science Today. 2021;8(3):560-563.

https://doi.org/10.14719/pst.2021.8.3.1209

Plant Science Today, published by Horizon e-Publishing Group, is covered by Scopus, Web of Science, BIOSIS Previews, Clarivate Analytics, etc. See https://horizonepublishing.com/journals/index.php/PST/indexing_abstracting 